\title{
Identification of novel protein kinase CK2 inhibitors among indazole derivatives
}

\author{
V. S. Vdovin, S. S. Lukashov, I. P. Borysenko, O. V. Borovykov, \\ M. V. Protopopov, V. G. Bdzhola, S. M. Yarmoluk \\ Institute of Molecular Biology and Genetics, NAS of Ukraine, \\ 150 Zabolotnogo St., 03680, Kyiv, Ukraine \\ Vdovin098599@gmail.com
}

\begin{abstract}
Aim. To synthesize the novel purine bioisosteres - indazole derivatives and evaluate inhibitory activity of these compounds towards CK2 in the in vitro system. Methods. Chemical synthesis, ${ }^{1} \mathrm{H}$ and ${ }^{13} \mathrm{C}$ NMR spectroscopy, LC-MS method, determination of residual enzyme activity using ATP consumption tests with a luciferase Kinase-Glo ${ }^{\circledR}$ luminescent kinase assay. Results. Known synthetic methods of indazole chemistry were originally applied to the synthesis of 3-aryl-indazole-7-carboxylic acids. Conditions of cross-coupling of 3-bromo-indazole derivatives with arylboronic acids were substantially improved. 3-aryl-indazole 5- and 7-carboxylic acids have shown $\mathrm{IC}_{50}$ in a range $3.1-6.5 \mu \mathrm{M}$ in luciferase luminescent kinase assay. Conclusions. The synthesis of 3-aryl-indazole-7-carboxylic acids has been developed. Novel inhibitors of the protein kinase CK2 among indazole derivatives have been identified among the 3-aryl-indazole 5- and 7-carboxylic acids. It has been shown the crucial impact of carboxyl group on the inhibitory activity of studied compounds.
\end{abstract}

Ke y w o r d s: Indazole, chemical synthesis, luciferase luminescent kinase assay, protein kinase inhibitor, protein kinase CK2.

\section{Introduction}

Casein kinase 2 (CK2) is a serine/threonine protein kinase usually consisting of two catalytic subunits $(\alpha)$ and/or $(\alpha$ ') and two regulatory $(\beta)$ subunits. This enzyme stands out among the most protein kinases by its high pleiotropicity. CK2 is involved in various biological processes - it has hundreds of substrates for phosphorylation [1] and can use both ATP and GTP as a phosphate source [2]. For a long time, this ubiquity was considered as an obstacle to use CK2 in the drug development until discovering the fact that cancer cells are much more dependent on CK2 than normal cells [3]. It has turned CK2 into an important player in overcoming drug resistance, albeit with some limitations [4]. Abnormally high

(C) 2021 V. S. Vdovin et al.; Published by the Institute of Molecular Biology and Genetics, NAS of Ukraine on behalf of Biopolymers and Cell. This is an Open Access article distributed under the terms of the Creative Commons Attribution License (http://creativecommons.org/licenses/by/4.0/), which permits unrestricted reuse, distribution, and reproduction in any medium, provided the original work is properly cited 
levels of CK2 occur during the various neurodegenerative, inflammatory, cardio-vascular diseases, virus infections and all the cancers having been examined $[5,6]$. This increased CK2 level having no genetic background often reduces the treatment efficiency, so until the reasons are not clarified the only possible way of attenuating CK2 activity is therapeutic use of the potent and selective CK2 inhibitors [7].

A number of CK2 inhibitors belonging to different chemical classes have been published [8-11] and one of them - silmitasertib (CX-4945) - is undergoing clinical trials now supporting the notion that $\mathrm{CK} 2$ is recognized as a druggable protein kinase. Therefore, the discovery of small-molecular CK2 inhibitors is a significant area of medicinal chemistry research.

Earlier, we found a number of chemical classes of CK2 inhibitors using the computeraided drug design approach. Here we are representing the CK2 inhibitors identified among the indazole derivatives. Purine bioisosteres are a common target in search for new binders of the ATP-binding site as protein kinase inhibitors [7]. The indazole carboxylic acid derivatives drew our attention for two reasons: the first - an indazole ring is a bioisostere of an adenine ring, the second - a carboxyl group is an essential part of several indazolecontaining CK2 inhibitors, such as 4,5,6,7-tetrabromo- $1 \mathrm{H}$-indazole and 3,4,5,6,7-pentabromo-1H-indazole derivatives [8], benzo[g]indazole derivatives [9] and a series of 4,6-disubstituted pyrazine derivatives including inhibitor CC04820. The silmitasertib (CX-4945) molecule also contains a carboxyl group involved in electrostatic interaction with the Lys68 of CK2 ATP-binding site. Thus, this work aims at the synthesis of indazole-carboxylic acids and related derivatives and evaluation of their inhibitory activity against CK2 in the in vitro system.

\section{Materials and Methods}

Starting materials and solvents were purchased from commercial suppliers and used without further purification. NMR spectra were recorded on a Varian VXR 400 instrument at $400 \mathrm{MHz}$ for ${ }^{1} \mathrm{H}$ NMR and $101 \mathrm{MHz}$ for ${ }^{13} \mathrm{C}$ NMR spectra. Chemical shifts are described as parts per million $(\delta)$ downfield from an internal standard of tetramethylsilane, and spin multiplicities are given as s (singlet), d (doublet), dd (double doublet), td (triple doublet), t (triplet), q (quartet), quintet (quintet) or $\mathrm{m}$ (overlapped multiplets). HPLC-MS analysis was performed using the Agilent 1100 LC/MSD SL separations module and Mass Quad G1956B mass detector with electrospray ionization (+ve or -ve ion mode as indicated), and HPLC was performed using a Zorbax SB-C18, Rapid Resolution HT cartridge, $4.6 \mathrm{~mm} \times 30 \mathrm{~mm}$, $1.8 \mu \mathrm{m}$ i.d. column (Agilent $\mathrm{P} / \mathrm{N}$ 823975-902) at a temperature of $40{ }^{\circ} \mathrm{C}$ with gradient elution of $0-100 \% \mathrm{CH}_{3} \mathrm{CN}$ (with $1 \mathrm{~mL} / \mathrm{L} \mathrm{HCOOH}$ )/ $\mathrm{H}_{2} \mathrm{O}$ (with $1 \mathrm{~mL} / \mathrm{L} \mathrm{HCOOH}$ ) at a flow rate of $3 \mathrm{~mL} / \mathrm{min}$ and a run time of $2.8 \mathrm{~min}$. Compounds were detected at $215 \mathrm{~nm}$ using a diode array G1315B detector. All tested compounds gave $\geq 95 \%$ purity as determined by these methods.

3-Phenyl-1H-indazole-7-carboxylic acid hydrochloride (8). Procedure A: The mixture of $1.00 \mathrm{~g}(2.71 \mathrm{mmol})$ of 1-tert-butyl-7-ethyl 3-bromoindazole-1,7-dicarboxylate 6, $0.35 \mathrm{~g}$ $(2.88 \mathrm{mmol})$ of phenylboronic acid, $0.50 \mathrm{~g}$ $(4.72 \mathrm{mmol})$ of sodium carbonate, $0.03 \mathrm{~g}$ $(0.136 \mathrm{mmol})$ of palladium diacetate, $0.10 \mathrm{~g}$ 
$(0.38 \mathrm{mmol})$ of triphenylphosphine, $15 \mathrm{ml}$ of ethanol and $5 \mathrm{ml}$ of water was refluxed under stirring in Ar atmosphere for 16 hours. After evaporation of solvents under reduced pressure the residue was diluted with $20 \mathrm{ml}$ of dichloromethane and $10 \mathrm{ml}$ of water, dark insoluble precipitate was filtered off and two layers were separated. Chromatographic purification of the residue after evaporation of the dichloromethane layer mixed with the insoluble precipitate gave $0.11 \mathrm{~g}(15 \%)$ of ethyl 3-phenyl-1H-indazole-7-carboxylate 7; ${ }^{1} \mathrm{H}$ NMR $(400 \mathrm{MHz}$, DMSO- $\left.d_{6}\right) \delta 13.16($ br s, $1 \mathrm{H}), 8.28(\mathrm{~d}, J=$ $7.7 \mathrm{~Hz}, 1 \mathrm{H}), 8.04(\mathrm{~d}, J=7.2 \mathrm{~Hz}, 1 \mathrm{H}), 7.96(\mathrm{~d}$, $J=7.6 \mathrm{~Hz}, 2 \mathrm{H}), 7.50(\mathrm{~d}, J=7.3 \mathrm{~Hz}, 2 \mathrm{H}), 7.39$ $(\mathrm{t}, J=7.8 \mathrm{~Hz}, 1 \mathrm{H}), 7.28(\mathrm{t}, J=7.6 \mathrm{~Hz}, 1 \mathrm{H})$, $4.50(\mathrm{q}, J=6.7 \mathrm{~Hz}, 2 \mathrm{H}), 1.45(\mathrm{t}, J=6.9 \mathrm{~Hz}$, $3 \mathrm{H})$. Acidification of the aqueous layer gave $0.32 \mathrm{~g}(43 \%)$ of precipitate of 3-phenyl-1Hindazole-7-carboxylic acid hydrochloride 8 as light grey powder m.p. $158^{\circ} \mathrm{C}{ }^{1} \mathrm{H}$ NMR $\left(400 \mathrm{MHz}, \mathrm{DMSO}-d_{6}\right) \delta 13.01(\mathrm{br} \mathrm{s}, 1 \mathrm{H}), 8.23$ $(\mathrm{d}, J=8.1 \mathrm{~Hz}, 1 \mathrm{H}), 8.00(\mathrm{~d}, J=7.2 \mathrm{~Hz}, 1 \mathrm{H})$, $7.94(\mathrm{~d}, J=7.4 \mathrm{~Hz}, 2 \mathrm{H}), 7.47$ (t, $J=7.3 \mathrm{~Hz}$, $2 \mathrm{H}), 7.36(\mathrm{t}, J=7.3 \mathrm{~Hz}, 1 \mathrm{H}), 7.25$ (t, $J=$ $7.7 \mathrm{~Hz}, 1 \mathrm{H}) .{ }^{13} \mathrm{C}$ NMR $\left(101 \mathrm{MHz}, \mathrm{DMSO}-d_{6}\right)$ $\delta 167.1,144.4,140.2,133.9,129.1,129.0$, $128.0,127.5,126.3,122.4,120.6,114.5$. LCMS (ESI) $\mathrm{t}_{\mathrm{r}}=0.886, \mathrm{~m} / \mathrm{z} 239.0\left([\mathrm{M}+\mathrm{H}]^{+}\right)$.

Procedure $B$ : The mixture of $1.00 \mathrm{~g}$ (2.71 mmol) of 1-tert-butyl-7-ethyl 3-bromoindazole-1,7-dicarboxylate $\mathbf{6}, 0.35 \mathrm{~g}$ $(2.88 \mathrm{mmol})$ of phenylboronic acid, $0.50 \mathrm{~g}$ $(4.72 \mathrm{mmol})$ of sodium carbonate, $0.03 \mathrm{~g}$ $(0.136 \mathrm{mmol})$ of palladium diacetate, $0.075 \mathrm{~g}$ $(0.135 \mathrm{mmol})$ of dppf, $15 \mathrm{ml}$ of ethanol and $5 \mathrm{ml}$ of water was refluxed under stirring in $\mathrm{Ar}$ atmosphere for 16 hours. Then $0.45 \mathrm{~g}(8 \mathrm{mmol})$ of potassium hydroxide were added and the mixture was refluxed for one more hour. After evaporation of solvents under reduced pressure the residue was diluted with $20 \mathrm{ml}$ of water, treated with charcoal and filtered. Acidification of the mother liquid gave $0.62 \mathrm{~g}(83 \%)$ of 3-phenyl-1H-indazole-7-carboxylic acid hydrochloride $\mathbf{8}$ as a light grey precipitate.

Procedure $C$ : The mixture of $1.00 \mathrm{~g}$ (2.71 mmol) of 1-tert-butyl-7-ethyl 3-bromoindazole-1,7-dicarboxylate $6,0.35 \mathrm{~g}(2.88 \mathrm{mmol})$ of phenylboronic acid, $0.80 \mathrm{~g}(7.14 \mathrm{mmol})$ of potassium tret-butoxide, $0.035 \mathrm{~g}(0.133 \mathrm{mmol})$ of Pd(dba $)_{2}, 0.085 \mathrm{~g}(0.137 \mathrm{mmol})$ of BINAP, $10 \mathrm{ml}$ of toluene was refluxed under stirring in $\mathrm{Ar}$ atmosphere for 16 hours. Solvent was evaporated under reduced pressure, the residue was diluted with $20 \mathrm{ml}$ of water, then $0.45 \mathrm{~g}$ $(8 \mathrm{mmol})$ of potassium hydroxide were added and the mixture was refluxed for one hour. After discoloration with charcoal and filtration the mother liquid was acidified giving $0.13 \mathrm{~g}$ (48\%) of 3-bromo-1H-indazole-7-carboxylic acid hydrochloride $\mathbf{1 5}$ as a light brown precipitate. ${ }^{1} \mathrm{H}$ NMR $\left(400 \mathrm{MHz}, \mathrm{DMSO}-d_{6}\right)$ $\delta 13.48(\mathrm{~s}, 1 \mathrm{H}), 8.06(\mathrm{~d}, J=7.2 \mathrm{~Hz}, 1 \mathrm{H}), 7.87$ $(\mathrm{d}, J=8.0 \mathrm{~Hz}, 1 \mathrm{H}), 7.34(\mathrm{t}, J=7.5 \mathrm{~Hz}, 1 \mathrm{H})$.

3-Pyridin-3-yl-1H-indazole-5-carbonitrile (9). As beige powder m.p. $108^{\circ} \mathrm{C} .{ }^{1} \mathrm{H}$ NMR (400 MHz, DMSO- $\left.d_{6}\right) \delta 13.78(\mathrm{~s}, 1 \mathrm{H}), 9.16$ $(\mathrm{s}, 1 \mathrm{H}), 8.57(\mathrm{~d}, J=6.8 \mathrm{~Hz}, 2 \mathrm{H}), 8.34(\mathrm{~d}, J=$ $7.9 \mathrm{~Hz}, 1 \mathrm{H}), 7.71(\mathrm{~d}, J=8.7 \mathrm{~Hz}, 1 \mathrm{H}), 7.61(\mathrm{~d}$, $J=8.6 \mathrm{~Hz}, 1 \mathrm{H}), 7.47(\mathrm{dd}, J=7.2,4.9 \mathrm{~Hz}, 1 \mathrm{H})$. ${ }^{13} \mathrm{C}$ NMR (101 MHz, DMSO- $\left.d_{6}\right) \delta 149.3$, 148.1, 142.8, 142.4, 134.5, 129.0, 128.4, 127.5, 124.0, 120.3, 119.7, 112.5, 104.5. LC-MS (ESI) $\mathrm{t}_{\mathrm{r}}=0.663, \mathrm{~m} / \mathrm{z} 221.0([\mathrm{M}+\mathrm{H}]+)$.

3-pyridin-3-yl-1H-indazole-5-carboxylic acid dihydrochloride (10). As beige powder m.p. $123^{\circ} \mathrm{C} .{ }^{1} \mathrm{H}$ NMR (400 MHz, DMSO- $d_{6}$ ) 
$\delta 13.60$ (br s, $1 \mathrm{H}), 12.50$ (br s, $1 \mathrm{H}), 9.14$ (br $\mathrm{s}, 1 \mathrm{H}), 8.62(\mathrm{~s}, 2 \mathrm{H}), 8.30(\mathrm{~d}, J=7.0 \mathrm{~Hz}, 1 \mathrm{H})$, $7.96(\mathrm{~d}, J=8.4 \mathrm{~Hz}, 1 \mathrm{H}), 7.62(\mathrm{~d}, J=8.4 \mathrm{~Hz}$, 1H), 7.53 (br s, $1 \mathrm{H}) .{ }^{13} \mathrm{C}$ NMR (101 MHz, DMSO- $\left.d_{6}\right) \delta 167.7,149.1,147.9,143.5,142.4$, 134.3, 129.4, 127.1, 124.2, 123.4, 120.2, 110.8. LC-MS (ESI) $\mathrm{t}_{\mathrm{r}}=0.565, \mathrm{~m} / \mathrm{z} 240.0([\mathrm{M}+\mathrm{H}]+)$.

3-(4-Methoxy-phenyl)-1H-indazole-5carboxylic acid (11). As white powder m.p. $246^{\circ} \mathrm{C} .{ }^{1} \mathrm{H}$ NMR $\left(400 \mathrm{MHz}, \mathrm{DMSO}-d_{6}\right) \delta 12.94$ (br s, 2H), $8.61(\mathrm{~s}, 1 \mathrm{H}), 7.93(\mathrm{~d}, J=8.6 \mathrm{~Hz}$, $1 \mathrm{H}), 7.87(\mathrm{~d}, J=8.2 \mathrm{~Hz}, 2 \mathrm{H}), 7.54(\mathrm{~d}, J=$ $8.7 \mathrm{~Hz}, 1 \mathrm{H}), 7.05(\mathrm{~d}, J=8.2 \mathrm{~Hz}, 2 \mathrm{H}), 3.83$ (s, 3H). ${ }^{13} \mathrm{C}$ NMR $\left(101 \mathrm{MHz}, \mathrm{DMSO}-d_{6}\right) \delta$ $167.8,159.5,145.1,143.6,128.4,126.8,126.2$, 124.0, 123.8, 120.2, 114.5, 110.3, 55.3. LC-MS (ESI) $\mathrm{t}_{\mathrm{r}}=0.794, \mathrm{~m} / \mathrm{z} 269.0([\mathrm{M}+\mathrm{H}]+)$.

3-(3-Fluoro-phenyl)-1H-indazole-5carboxylic acid (12). As beige powder m.p. $86{ }^{\circ} \mathrm{C} .{ }^{1} \mathrm{H}$ NMR $\left(400 \mathrm{MHz}, \mathrm{DMSO}-d_{6}\right) \delta 13.44$ (br s, 1H), 12.67 (br s, 1H), $8.63(\mathrm{~s}, 1 \mathrm{H}), 7.95$ $(\mathrm{d}, J=8.2 \mathrm{~Hz}, 1 \mathrm{H}), 7.79(\mathrm{~d}, J=7.7 \mathrm{~Hz}, 1 \mathrm{H})$, $7.67(\mathrm{~d}, J=10.0 \mathrm{~Hz}, 1 \mathrm{H}), 7.58(\mathrm{~d}, J=8.9 \mathrm{~Hz}$, $1 \mathrm{H}), 7.53(\mathrm{t}, J=6.4 \mathrm{~Hz}, 1 \mathrm{H}), 7.14(\mathrm{t} \mathrm{d}, J=$ 8.24, $1.93 \mathrm{~Hz}, 1 \mathrm{H}) .{ }^{13} \mathrm{C}$ NMR (101 MHz, DMSO- $\left.d_{6}\right) \delta 167.9,164.2(\mathrm{~d}, J=245.1 \mathrm{~Hz})$, 144.0, 143.8, 136.1 (d, $J=7.5 \mathrm{f} \mathrm{Hz}), 131.0$ (d, $J=7.8 \mathrm{~Hz}), 127.1,124.5,123.7,123.1$, $120.2,115.0(\mathrm{~d}, J=20.0 \mathrm{~Hz}), 113.9(\mathrm{~d}, J=$ $23.0 \mathrm{~Hz}), 110.8$. LC-MS (ESI) $\mathrm{t}_{\mathrm{r}}=0.821$, $\mathrm{m} / \mathrm{z} 257.0([\mathrm{M}+\mathrm{H}]+)$.

3-(4-Fluoro-phenyl)-1H-indazol-5-ylamine (13). As light brown powder m.p. $98^{\circ} \mathrm{C} .{ }^{1} \mathrm{H}$ NMR (400 MHz, DMSO- $\left.d_{6}\right) \delta 12.72$ (br s, $1 \mathrm{H}), 7.92(\mathrm{br} \mathrm{s}, 2 \mathrm{H}), 7.28(\mathrm{~d}, J=8.7 \mathrm{~Hz}, 1 \mathrm{H})$, 7.20 (t, $J=8.3 \mathrm{~Hz}, 2 \mathrm{H}), 7.13(\mathrm{~s}, 1 \mathrm{H}), 6.84$ (d, $J=8.3 \mathrm{~Hz}, 1 \mathrm{H}), 4.60$ (br s, $2 \mathrm{H}) .{ }^{13} \mathrm{C} \mathrm{NMR}$ $\left(101 \mathrm{MHz}, \mathrm{DMSO}-d_{6}\right) \delta 162.8(\mathrm{~d}, J=$ $244.3 \mathrm{~Hz}), 142.3,140.6,136.8,131.5,128.2$ $(\mathrm{d}, J=6.7 \mathrm{~Hz}), 121.2,118.4,115.5(\mathrm{~d}, J=$ $21.2 \mathrm{~Hz}), 111.0,101.6$. LC-MS (ESI) $\mathrm{t}_{\mathrm{r}}=$ $0.613, \mathrm{~m} / \mathrm{z} 228.0([\mathrm{M}+\mathrm{H}]+)$.

3-(4-Fluoro-phenyl)-1H-indazole-5carbonitrile hydrochloride (14). As white powder m.p. $135^{\circ} \mathrm{C} .{ }^{1} \mathrm{H}$ NMR $(400 \mathrm{MHz}$, DMSO- $\left.d_{6}\right) \delta 13.74($ br s, $1 \mathrm{H}), 8.53(\mathrm{~s}, 1 \mathrm{H})$, $7.94(\mathrm{~d}, J=8.2 \mathrm{~Hz}, 1 \mathrm{H}), 7.92(\mathrm{~d}, J=1.1 \mathrm{~Hz}$, $1 \mathrm{H}), 7.70(\mathrm{~d}, J=8.7 \mathrm{~Hz}, 1 \mathrm{H}), 7.60(\mathrm{~d}, J=$ $8.7 \mathrm{~Hz}, 1 \mathrm{H}), 7.48(\mathrm{t}, J=7.8 \mathrm{~Hz}, 1 \mathrm{H}), 7.37(\mathrm{~d}$, $J=7.1 \mathrm{~Hz}, 1 \mathrm{H}) .{ }^{13} \mathrm{C}$ NMR $(101 \mathrm{MHz}$, DMSO- $\left.d_{6}\right) \delta 142.7(\mathrm{~d}, J=244.3 \mathrm{~Hz}), 134.9$, 134.3, 130.6, 128.1, 127.3, 126.8, 125.7, 120.0, $119.5,112.4,104.3$. LC-MS (ESI) $\mathrm{t}_{\mathrm{r}}=1.002$, $\mathrm{m} / \mathrm{z} 238.0([\mathrm{M}+\mathrm{H}]+)$.

The enzyme activity of protein kinase CK2 was determined using ATP consumption tests. Each reaction mixture contained $3 \mu \mathrm{l}$ of buffer solution $(20 \mathrm{mM}$ Tris- $\mathrm{HCl} \mathrm{pH} 7.5,50 \mathrm{mM}$ $\left.\mathrm{KCl}, 10 \mathrm{mM} \mathrm{MgCl}_{2}\right), 3 \mu \mathrm{l}$ of peptide substrate RRRDDDSDDD ( $2 \mathrm{mg} / \mathrm{ml}), 0.02 \mu \mathrm{l}$ (10 units) of recombinant human $\mathrm{CK} 2 \alpha$ catalytic subunit obtained by us [10], $13 \mu \mathrm{l}$ of $\mathrm{H}_{2} \mathrm{O}$ and $1 \mu \mathrm{l}$ of inhibitor $300 \mu \mathrm{M}$ stock solution in dimethylsulfoxide (DMSO).

The reaction was started with addition of $10 \mu \mathrm{l}$ of $3^{\mathrm{x}}$ ATP solution ( $30 \mu \mathrm{M}$ ATP, $30 \mathrm{mM}$ $\mathrm{MgCl}_{2}, 15 \mathrm{mM}$ MOPS pH 7.2) to each microplate well. The microplate was put on "TERMIT" incubator and incubated at $31{ }^{\circ} \mathrm{C}$ for $20 \mathrm{~min}$.

The reaction was stopped by adding $30 \mu \mathrm{l}$ of luciferase mix (Kinase-Glo ${ }^{\circledR}$ Luminescent Kinase Assay, Promega) to each microplate well. Luciferase suppresses ATP consumption by kinase and starts the luciferase reaction. The luminescence was counted with Victor reader using Dual Luciferase assay protocol. The heating option on "Victor" was switched on $21^{\circ} \mathrm{C}$. 


\section{Results}

In order to provide enough hydrophobic interactions to keep binding in the pocket of ATPbinding site we have focused on a synthesis of indazole-carboxylic acids carrying the arylmoiety at the 3-rd position of the indazole ring.

The synthesis of 3-aryl-indazole-5-carboxylic acid derivatives as the inhibitors of various protein kinases was reported earlier [11-14]. At the same time only few instances of synthesis of indazole-7-carboxylic acids and no examples of synthesis of 3-aryl-substituted indazole-7-carboxylic acids have been reported. Here we are representing a method of synthesis of 3-phenyl-indazole-7-carboxylic acid that can be easily applied to the synthesis of any 3-aryl-substituted indazole-7-carboxylic acid. We have used synthetic methods known for indazole derivatives with other substitution. The indazole ring assembly starts from the 3-methyl-anthranilic acid 1 ester (Fig. 1). Bromination or iodination of the indazole-7-carboxylic acid ester 2 leads to the 3-halogeno-substituted intermediates 3 [15] that could possibly be converted into the 3 -aryl-indazole-7-carboxylic acid 4 esters under the Suzuki-Miyaura cross-coupling conditions. This convenient synthetic route may involve a wide range of aryl- and heteroaryl-boronic acids, however, it requires additional steps of protection/deprotection of $\mathrm{NH}$ on the indazole ring. The halogen on the 3-rd position of the indazole ring shows no reactivity unless it's $\mathrm{NH}$ is covered with a protective group, moreover, $\mathrm{NH}$-arylation with the arylboronic acids takes place under the same conditions as crosscoupling.

Moving along this synthetic route (Scheme 1) we have obtained the ethyl indazole-7-carboxylate $\mathbf{2}$ in moderate yield by the nitrosylation of the ethyl 3-methylanthranilate 1 with tret-butylnitrite in acetic acid. After the bromination and the N-Boc protection, this intermediate was used in the Suzuki-Miyaura cross-coupling with phenylboronic acid. Several attempts were unsuccessful. The crosscoupling product was not formed when BINAP-Pd(0), tBuOK in toluene were used. However, the ethyl 3-phenyl-indazole-7-carboxylate appeared in the reaction mixture when the reaction ran in aqueous ethanol media in presence of $\mathrm{Pd}\left(\mathrm{PPh}_{3}\right)_{4}$ and $\mathrm{Na}_{2} \mathrm{CO}_{3}$ as a base. The replacement of $\mathrm{Pd}\left(\mathrm{PPh}_{3}\right)_{4}$ with $\mathrm{Pd}(\mathrm{OAc})_{2} / \mathrm{dppf}$ enhanced the yield of the process. Noteworthy, under the conditions of mentioned reaction the indazole moiety completely lost its N-Boc protection. Additionally, a significant amount - up to half the ethyl es-
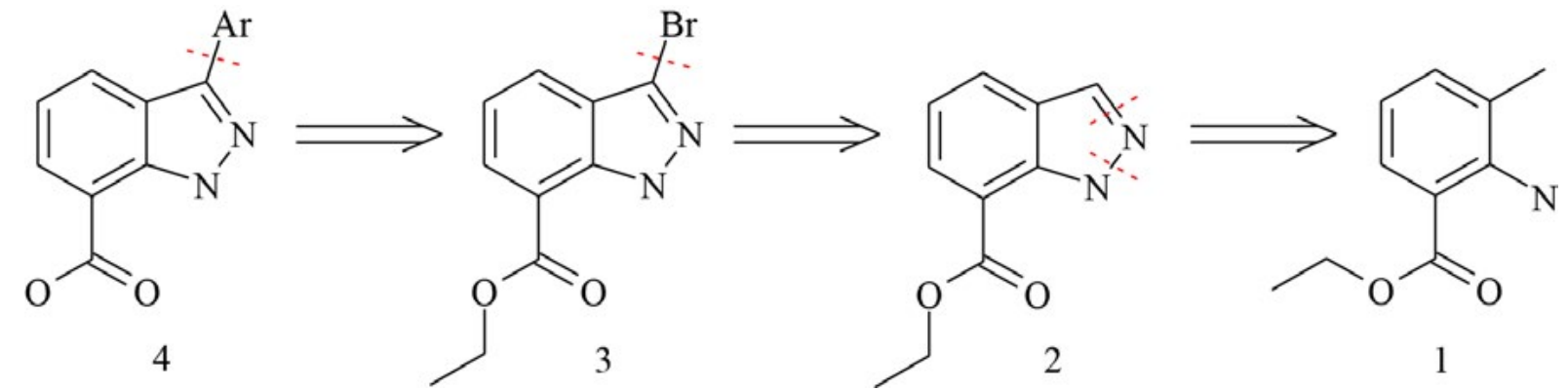

Fig. 1. Preparation of the 3-aryl-indazole-7-carboxylic acids from an indazole-7-carboxylic acid ester. 
<smiles>CCOC(=O)c1cccc(C)c1N</smiles><smiles>CCOC(=O)c1cccc2c1=C1N[NH+]=C(C(c3ccccc3)=NNc3c(C(=O)O)cccc31)C=2c1ccccc1</smiles>

Fig. 2. Conditions: a: $\mathrm{AcOH}, t \mathrm{BuONO}, 10^{\circ} \mathrm{C} \div$ r.t., 12h; b: NBS, DMF, r.t., $8 \mathrm{~h} ; \mathrm{c:} \mathrm{Boc}_{2} \mathrm{O}$, dioxane, reflux, 1h; d: $\mathrm{PhB}(\mathrm{OH})_{2}$, $\mathrm{Na}_{2} \mathrm{CO}_{3}, \mathrm{Pd}(\mathrm{OAc})_{2}$, dppf, EtOH, $\mathrm{H}_{2} \mathrm{O}$, reflux, overnight. ter — underwent hydrolysis, so, it turned out reasonable to complete the hydrolysis by adding $\mathrm{KOH}$ and refluxing for one more hour before the isolation of the final product. The isolation of carboxylic acid also has an advantage - the rest of a catalyst and most impurities can be easily removed from the basic aqueous solution with further precipitation of the 3-phenyl-indazole-7-carboxylic acid after acidification (Fig. 2).

5-substituted 3-aryl-1H-indazoles 9-14 were synthesized following known procedures.

\section{Discussion}

We have tested the compounds 8-14 for inhibitory activity toward human CK $2 \alpha$ catalytic subunit using Kinase-Glo ${ }^{\circledR}$ Luminescent Kinase Assay. The chemical structure of substituents and $\mathrm{IC}_{50}$ values are presented in Table 1.

Several important structural features of indazole derivatives can be identified from a qualitative analysis of their activity toward CK2. As can be seen from Table 1, CK2 inhibitory activity of the studied derivatives

Table 1. Structure and inhibitory activity towards CK2 of indazole derivatives.

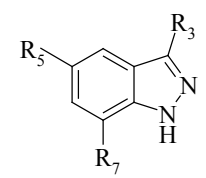

\begin{tabular}{|c|c|c|c|c|}
\hline Cpd & $\mathbf{R}_{3}$ & $\mathbf{R}_{5}$ & $\mathbf{R}_{7}$ & $\mathrm{IC}_{50}, \boldsymbol{\mu M}$ \\
\hline 8 & & $\mathrm{H}$ & $\mathrm{COOH}$ & 5.2 \\
\hline 9 & & $\mathrm{CN}$ & $\mathrm{H}$ & $>10$ \\
\hline 10 & & $\mathrm{COOH}$ & $\mathrm{H}$ & 3.4 \\
\hline 11 & & $\mathrm{COOH}$ & $\mathrm{H}$ & 5.1 \\
\hline 12 & & $\mathrm{COOH}$ & $\mathrm{H}$ & 6.5 \\
\hline 13 & & $\mathrm{NH}_{2}$ & $\mathrm{H}$ & $>10$ \\
\hline 14 & & $\mathrm{CN}$ & $\mathrm{H}$ & $>10$ \\
\hline
\end{tabular}


strongly depends on the presence of a carboxyl group in their structures regardless of the position in phenyl moiety. Compound 8 with a carboxyl group at the 7-th position of the indazole ring shows the same level of inhibition of CK2 as compounds 10-12 with a carboxyl group at the 5-th position. In our opinion[, the] electrostatic interaction between negatively charged carboxylate and side chain residues of the ATP-binding pocket of CK2 plays an important role in the affinity of compounds 8 and 10-12. Compounds 9 and 14 having neutral nitrile group (which meanwhile can act as a hydrogen bond acceptor in the same way as carboxylate) demonstrate no inhibitory activity unlike the corresponding carboxylic acid derivatives. Compound $\mathbf{1 3}$ with the slightly basic hydrogen bond donor amino group also shows no inhibitory activity. The structure of the aromatic $\mathrm{R}_{3}$ substituents in a range of the studied compounds seems not to be important. A slight advantage of the pyridine moiety over phenyl rings among other reasons may be a result of the contribution of higher polarity pyridine ring in the water solubility of the compound.

\section{Conclusion}

The synthesis of 3-aryl-indazole-7-carboxylic acid has been developed. Novel inhibitors of the protein kinase CK2 among indazole derivatives have been identified. The activity of the studied compounds strongly depends on the presence of carboxyl group as substituent $\mathrm{R}_{5}$ or $\mathrm{R}_{7}$. The identified indazole derivatives have shown promising inhibitory activity toward CK2, although they require further chemical optimization and biological investigations.

\section{Funding}

This research was supported by grants from the National Academy of Sciences of Ukraine (0107U003345 and 0107U004939).

\section{Conflict of Interest}

None

\section{REFERENCES}

1. Bian $Y$, Ye $M$, Wang $C$, Cheng $K$, Song $C$, Dong $M$, Pan Y, Qin H, Zou H. Global screening of CK2 kinase substrates by an integrated phosphoproteomics workflow. Sci Rep. 2013; 3(3460):1-7.

2. Ahmad KA, Wang G, Unger G, Slaton J, Ahmed K. Protein kinase CK2 - a key suppressor of apoptosis. Advances in Enzyme Regulation. 2008; 48:17987.

3. Ruzzene M, Pinna LA. Addiction to protein kinase CK2: a common denominator of diverse cancer cells? Biochim Biophys Acta. 2010; 1804(3):499504.

4. Christian Borgo and Maria Ruzzene Role of protein kinase CK2 in antitumor drug resistance. J Exp Clin Cancer Res. 2019; 38:287.

5. Wilson LK, Dhillon N, Thorner J, Martin GS. Casein kinase II catalyzes tyrosine phosphorylation of the yeast nucleolar immunophilin Fpr3. J Biol Chem. 1997; 272(20):12961-12967.

6. Faust M, Montenarh M. Subcellular localization of protein kinase CK2: A key to its function? Cell Tissue Res. 2000; 301(3):329-340.

7. Sarno $S$, Pinna LA. Protein kinase CK2 as a druggable target. Mol Biosyst. 2008; 4(9):889-894.

8. Sarno S, Reddy H, Meggio F, Ruzzene M, Davies SP, Donella-Deana A, Shugar D, Pinna LA. Selectivity of 4,5,6,7-tetrabromobenzotriazole, an ATP sitedirected inhibitor of protein kinase CK2 ('casein kinase-2'). FEBS Lett. 2001; 496(1):44-48.

9. Battistutta R, De Moliner E, Sarno S, Zanotti G, Pinna LA. Structural features underlying selective inhibition of protein kinase CK2 by ATP site-directed tetrabromo-2-benzotriazole. Protein Sci. 2001; 10(11):2200-2206. 
10. Szyszka R, Grankowski N, Felczak K, Shugar D. Halogenated benzimidazoles and benzotriazoles as selective inhibitors of protein kinases CK I and CK II from Saccharomyces cerevisiae and other sources. Biochim Biophys Res Commun. 1995; 208(1):418-424.

11. Pagano M, Andrzejewska M, Ruzzene M, Sarno S, Cesaro L, Bain J, Elliott M, Meggio F, Kazimierczuk Z, Pinna LA. Optimization of protein kinase CK2 inhibitors derived from 4,5,6,7-tetrabromobenzimidazole. J Med Chem. 2004; 47(25):6239-6247.

12. Wasik R, Wińska P, Poznański J, Shugar D. Isomeric mono-, di-, and tri-bromobenzo-1H-triazoles as inhibitors of human protein kinase CK $2 \alpha$. PLoS One. 2012; 7(11):e48898.

13. Gianoncelli A, Cozza G, Orzeszko A, Meggio F, Kazimierczuk Z, Pinna LA. Tetraiodobenzimidazoles are potent inhibitors of protein kinase CK2. Bioorg Med Chem. 2009; 17(20):7281-7289.

14. Meggio F, Shugar D, Pinna L. Ribofuranosyl-benzimidazole derivatives as inhibitors of casein kinase-2 and casein kinase-1. Eur J Biochem. 1990; 187(1):89-94.

15. Yim H, Lee $Y$, Lee $S$. Emodin, an anthraquinone derivative isolated from the rhizomes of Rheum palmatum, selectively inhibits the activity of casein kinase II as a competitive inhibitor. Planta Med. 1999; 65(1):9-13.

\section{Ідентифікація нових інгібіторів протеїнкінази СК2 серед похідних індазолу}

В. С. Вдовін, С. С. Лукашов, І. П. Борисенко, О. В. Боровиков, М. В. Протопопов, В. Г. Бджола, С. М. Ярмолюк

Мета. Синтез нових біоізостерів пурину - похідних індазолу та перевірка інгібувальної активності отриманих сполук щодо протеїнкінази СК2 в системі in vitro. Методи. Хімічний синтез, спектроскопія ${ }^{1} \mathrm{H}$ та ${ }^{13} \mathrm{C}$ ЯМР, метод ВЕРХ з мас-детектором. Визначення залишкової ензимної активності за витратою АТФ і люмінесценцією люциферазної реакції в системі Kinase-Glo®. Результати. Відомі синтетичні методи хімії індазолу було вперше застосовано для синтезу 3-арил-індазол-7-карбонових кислот. Було суттєво вдосконалено умови крос-сполучення похідних 3-бром-індазолу з арилбороновими кислотами. 3-арил- індазол 5- та 7-карбонові кислоти продемонстрували в люциферазному кіназному тесті $\mathrm{IC}_{50}$ в межах 3.1$6.5 \mu \mathrm{M}$. Висновки. Було розроблено синтез 3-ариліндазол-7-карбонових кислот. Серед похідних 3-ариліндазол 5- та 7-карбонових кислот було знайдено нові інгібітори протеїнкінази СК2. Було продемонстровано вирішальний вплив карбоксильної групи на інгібувальну активність досліджених сполук.

К л ю ч о в і с л о в а: Індазол, хімічний синтез, люмінесцентний люциферазний тест, інгібітор протеїнкінази, протеїнкіназа СК2.

\section{Идентификация новых ингибиторов протеинкиназы CK2 среди производных индазола}

В. С. Вдовин, С. С. Лукашов, І. П. Борисенко, А. В. Боровиков, Н. В. Протопопов, В. Г. Бджола, С. М. Ярмолюк

Цель. Синтез новых биоизостеров пурина -производных индазола и проверка ингибирующей активности полученных соединений относительно протеинкиназы СК2 в системе in vitro. Методы. Химический синтез, спектроскопия ЯМР на ядрах ${ }^{1} \mathrm{H}$ и ${ }^{13} \mathrm{C}$, метод ВЭЖХ с масс-детектором. Определение остаточной энзимной активности по расходу АТФ и люминесценции люциферазной реакции в системе Kinase-Glo®. Результаты. Известные синтетические методы химии индазола были впервые применены для синтеза 3-арил-индазол-7-карбоновых кислот. Были существенно усовершенствованы условия кросс-сочетания производных 3-бром-индазола с арилборными кислотами. 3-арил-индазол 5- и 7-карбоновые кислоты продемонстрировали в люциферазном киназном тесте $\mathrm{IC}_{50}$ в пределах $3.1-6.5 \mu \mathrm{M}$. Выводы. Был разработан синтез 3-арил-индазол-7-карбоновых кислот. Среди производных 3-арил-индазол 5- и 7-карбоновых кислот были обнаружены новые ингибиторы протеинкиназы СК2. Было продемонстрировано решающее влияние карбоксильной группы на ингибирующую активность исследованных соединений.

К л юче в ы е с л о в а: Индазол, химический синтез, люминесцентный люциферазный тест, ингибитор протеинкиназы, протеинкиназа СК2.

Received 10.03.2021 